\title{
Study on fungicidal effect of plant extracts on plant pathogenic fungi and the economy of extract preparation and efficacy in comparison to synthetic/chemical fungicides
}

\begin{abstract}
Jyoti Singh*
Department of Botany, Banaras Hindu University, Varanasi (Uttar Pradesh), India

S. K. Bhatnagar

College of Biotechnology, Sardar Vallabhbhai Patel University of Agriculture and Technology, Meerut (Uttar Pradesh), India

Akash Tomar

College of Biotechnology, Sardar Vallabhbhai Patel University of Agriculture and Technology, Meerut (Uttar Pradesh), India

${ }^{*}$ Corresponding author. E-mail: singh.jyoti146@gmail.com

Abstract

Providing food security to devastatingly increasing population with limited natural resources along with destruction caused by pre- and post-harvest pathogens are the foremost concerns for the developing countries. Numerous pesticides, herbicides and chemical fertilizers are being applied by the farmers to deal with the existing situation but leave very disastrous and undesirable after effects on ecosystem as non-degradable molecules.. Botanicals can be utilized as an ecofriendly and effective alternative against chemical as they are of natural origin. In this context, two chemical/synthetic fungicides namely Manzate and Nystanin in three different concentrations namely 500ppm, 1000 ppm and 1500 ppm were evaluated against Sclerotium rolfsii, Alternaria alternata, Fusarium monilifrome, Rhizoctonia solani and Aspergillus niger in vitro to compare them with ethanolic botanical extracts of spices (clove, cinnamon, thyme) and weeds (parthenium and calotropis) at $5 \%, 10 \%, 15 \%, 20 \%$ and $25 \%$. Results revealed the high efficacy of botanicals i.e. clove extracts showed maximum inhibition $(100 \%)$, followed by reduced inhibition in cinnamon, thyme, Parthenium and Calotropis treated plates against all five pathogens even at $5 \%$ concentration in comparison to chemical of $500 \mathrm{ppm}$ concentration i.e. $100 \%$ in case of S.rolfsii only. Hence the herbal products can be further analyzed and applied as a potent, ecofriendly and economical substitute to chemicals.
\end{abstract}

Keywords: Agrochemicals, Botanical extracts, Food security, Phytopathogens

\section{INTRODUCTION}

Agriculture is an important sector of Indian economy as it contributes about $17 \%$ of total GDP and provides employment to about $60 \%$ of population (GOI, 2011). Nowadays a considerable issue faced by country is production of quality crop to feed enormously growing population with limited natural resources. About $10-30 \%$ crop loss caused by microbes, pests, insects, etc. is enhancing the pressure on existing problematic situation (Kumar and Gupta, 2012). Various type of direct and indirect losses caused by plant diseases include, reduced quality and quantity of crop produce, increased cost of production, threat to animal health and environment, loss of natural resources and less remunerative alternatives adopted (Kumar and Saxena, 2009). Fungi are the most important cause of plant disease (Persley, 1993), since they are the most widespread and destructive parasites of plants (Ingold and Hudson, 1993). Farmers

\section{Article Info}

DOI:10.31018/jans.v11i2.2053 Received: April 4, 2019

Revised: May 2, 2019

Accepted: May 5, 2019

\section{How to Cite}

Singh, J. et al. (2019). Study on fungicidal effect of plant extracts on plant pathogenic fungi and the economy of extract preparation and efficacy in comparison to synthetic/ chemical fungicides. Journal of Applied and Natural Science, 11(2): 333- 337 https://doi.org/10.31018/ jans.v11i2.2053 
Herbal products are again gaining attention due to relatively lower incidence of adverse reactions to plant preparations compared to modern conventional pharmaceuticals and their even their reduced cost (Lulekal et al., 2008). Extracts isolated from several plants have reported to posses biological activity such as antimicrobial, antifungal and anti-inflammatory abilities due to the presence of bioactive compounds like alkaloids, glycosides, resins, volatile oils, gums and tannins, etc. (Yusuf et al., 2001). Natural products, either as pure compounds, or standardized plant extracts, provide unlimited opportunities for new drug leads because of the unmatched availability of chemical diversity in the plant kingdom (Cos et al., 2006; Maregesi et al., 2008). Over $50 \%$ of all modern clinical drugs are of natural origin and natural products play an important role in drug development programs in the pharmaceutical industry (Farombi et al., 2003; Nair and Chandra, 2005). Spices and herbs have been used as food additives since ancient times as flavouring agents and also as natural food preservatives. Previous studies revealed very strong antifungal activity of essential oils from spices and herbs, such as garlic, mustard, cinnamon, cumin, clove, bay, thyme, basil, oregano, pepper, ginger, sage, rosemary etc., against most common fungi that contaminate food (Aspergillus spp., Cladosporium spp. and many others) (Gupta, 2013; Skrinjar and Nemet, 2009). Yet in spite of the scale of this research enterprise, only a handful of botanical insecticides are in commercial use on vegetable and fruit crops today, with significant commercial development of only two new sources of botanicals in the past 20 years (Dreistadt, 2003). Keeping in view the importance of disease management for crops in an economical and environmental friendly mode, the present study was conducted to compare the fungicidal efficacy and cost of production between plant extracts and synthetic/chemical fungicides.

\section{MATERIALS AND METHODS}

The experiment was conducted in the laboratory of Department of Commercial Biotechnology, College of Biotechnology, Sardar Vallabhbhai Patel University of Agriculture and Technology, Modipuram, Meerut (Uttar Pradesh). The university is situated on Dehradun - Delhi NH-58 at a distance of $10.0 \mathrm{~km}$. away in the North of Meerut city between 73 and $74 \mathrm{~km}$. on National highway. Geographically, Meerut is located at $29^{\circ} 05^{\prime} 50^{\prime \prime}$ North latitude, $77^{\circ} 41^{\prime} 50^{\prime \prime}$ East longitudes and at an altitude of 237 meter above the mean sea level. The plant pathogenic fungal strains of Sclerotium rolfsii, Alternaria alternate, Fusarium moniliformae, Aspergillus niger and Rhizoctonia solani were collected from Department of plant pathology, Recombinant techniques and Agriculture Bio- technology.

Preparation of botanical extracts and synthetic fungicide solution: Clove bud, Cinnamon bark, Thyme seeds, Parthenium hysterophorus and Calotropis procera were surface sterilized by using $0.01 \% \mathrm{HgCl}_{2}$, dried hot air oven $\left(40 \pm 2^{\circ} \mathrm{C}\right)$ for 24 hours and were coarsely powdered. To obtain the defined concentrations of $5 \%, 10 \%, 15 \%, 20 \%$ and $25 \%$, mentioned amount of $50 \mathrm{mg}, 100 \mathrm{mg}$, $150 \mathrm{mg}, 200 \mathrm{mg}$ and $250 \mathrm{mg}$ botanical powder was immersed separately in $50 \mathrm{ml}$ ethanol (50\%) in $100 \mathrm{ml}$ conical flask respectively and were kept in shaker incubator at $\left(40 \pm 2^{\circ} \mathrm{C}\right)$ for 24 hours. The extracts were obtained by filtering through Whatman filter paper No. 1 and kept at $50^{\circ} \mathrm{C}$ in water bath thus allowing ethanol to evaporate. Then the remains were weighed and diluted with $10 \%$ DMSO according to the weight $(5 \mathrm{ml} / \mathrm{gm})$ for preparing final concentrations which were preserved in a refrigerator at $4^{\circ} \mathrm{C}$ till use (Barreto et al., 2002; Chen et al., 1987).

The synthetic fungicides namely Nystatin (Srivastava and Singh, 2011) and Mancozeb (Jagtap et al., 2013) were procured from market in powdered form. To prepare solution of three different concentrations of 500ppm, 1000ppm and $1500 \mathrm{ppm}$, solvent were mixed with $0.5 \mathrm{mg} / \mathrm{ml}, 1.0$ $\mathrm{mg} / \mathrm{ml}$ and $1.5 \mathrm{mg} / \mathrm{ml}$ respectively (w/v).

Screening of antifungal activity of extracts: Both botanicals extracts and synthetic fungicidal solution were evaluated against plant pathogenic fungi through poisoned food technique by mixing them with cooled $\left(45^{\circ} \mathrm{C}\right)$ molten Potato Dextrose Agar medium in concentration of 1:9 (llyas et al., 1982). Petri-plates with different concentration of ethanolic extracts were inoculated with mycelial disc of $6 \mathrm{~mm}$ diameter from the periphery of 7 day old cultures of S.rolfsii, A. alternata, F.monilifrome, R. solani and A.niger and incubated at $25^{\circ} \mathrm{C}$ for invitro studies. PDA plates with $100 \mu$ of DMSO were used as negative control whereas plates without any solvent were positive control (Georgii and Korting, 1991, McCutcheon et al., 1994). The evaluation was performed by measuring the colony diameter of pathogenic fungi at interval of 24 hour from the inoculation (Florl et al., 2003, Rasooli and Abyanek, 2004). The results were expressed in terms of the percent inhibition in diameter of mycelia. Radial mycelia growth was recorded and was further converted to percent inhibition. Variation of each strain on test plate as compared to control plate for every extract and fungicide has been calculated by the formula given:

Percent growth inhibition over control $=\mathrm{C}-\mathrm{T} / \mathrm{C} \mathrm{X}$ $100 \quad$......Eq.1 Where: $\mathrm{C}=$ Growth of fungus in control, $\mathrm{T}=$ Growth of fungus in treatment

Comparative study of chemical and biological fungicides production cost: The comparative study of synthetic and botanical fungicides was 
also made to evaluate them on economical basis. The cost of defined amount of spices that include clove, cinnamon and thyme, utilized in extract preparation of different concentration was compared to the cost of same amount of synthetic fungicides Nystatin and Manzate (Mancozeb).

\section{RESULTS AND DISCUSSION}

Effect of different botanical extracts on plant pathogenic fungi in in-vitro: The results of investigation for testing the efficacy of ethanolic extracts of spices and weeds showed that the ethanolic extracts of clove, cinnamon, thyme, Parthenium and Calotropis at different concentrations i.e. $5 \%, 10 \%, 15 \%, 25 \%$ and $25 \%$ respectively, showed antifungal activity against S.rolfsii, A.alternata, F.monilifrome, R.solani and A.niger under in-vitro conditions. After three days of inoculation in control plates (i.e. without extracts) and test plates (i.e. with extracts), the inhibition in growth of mycelium of plant pathogenic fungal strains under the influence of various treatments of botanical extracts is presented in table 1.

Table clearly indicate the radius of mycelial growth pattern of $S$. rolfsii, A.alternata, F.monilifrome, R.solani and A.niger under in-vitro conditions on control plates and on the test plates with different concentration of the ethanolic extracts. The plates with clove extracts showed maximum inhibition i.e. no growth, followed by reduced inhibition in cinnamon, thyme, Parthenium and Calotropis treated plates with little variation in some. It depicts that all the botanical extracts show antifungal activity against plant pathogenic fungal strains.

Effect of different synthetic fungicides on plant pathogenic fungi in-vitro: A comparison of the fungicidal activity of synthetic fungicides viz. Mancozeb and Nystatin at three different concentrations i.e. 500ppm, 1000ppm and 1500ppm against plant pathogenic fungi viz. S.rolfsii, A.alternata, F.monilifrome, R.solani and A.niger under in-vitro conditions after three days is mentioned in table 2 and 3.

The data recorded in bioassay experiment done with poisoned food technique shown in tables revealed that all fungicides were found significantly superior over the control (untreated) due to the inhibition of growth of test pathogens under in-vitro conditions. Results depicted that Nystatin was the best fungicide which completely inhibited the radial growth of S.rolfsii and A.niger i.e. zero growth at all three concentrations followed by A.alternata and R.solani whereas Mancozeb mainly inhibited $F$. monilifrome. These fungicides inhibited the pathogenic fungal strains to a nearby range as compared to botanical extracts, varying to some extent in case of Calotropis, in different concentrations except clove which showed zero growth at low concentration. It can be clearly depicted that clove extract can be used as an effective biological fungicides because $100 \%$ inhibition was observed for all the five plant pathogenic fungi viz. S.rolfsii, A.alternata, F.monilifrome, R.solani and A.niger under in-vitro conditions. Cinnamon extract was found to be more effective inhibitor of R.solani whereas thyme extract was found to be most effective for A.alternate. The extracts obtained from Parthenium and Calotropis showed considerably less inhibition as compared to the extracts of spices and synthetic fungicides. A. niger was found to be least sensitive to Calotropis extract whereas $R$. solani was found to be least sensitive to Parthenium extract.

Data presented in table clearly indicate that S.rolfsii is highly sensitive with $100 \%$ inhibition to both of the synthetic fungicides viz. Mancozeb and Nystatin in all three concentrations. Nystatin inhibited A.niger completely in all the three concentrations. Experimental observations witness that Nystatin is more effective to all plant pathogenic strains viz. S.rolfsii, A.alternata, F.monilifrome, R.solani and A.niger under in-vitro conditions whereas Mancozeb show significant inhibition of F.monilifrome with relatively low inhibitory effect on other fungal strains as compared to Nystatin. Calotropis leaf extracts were screened by Sasode and Singh for antifungal activity against fungal pathogen and were further compared with Mancozeb. Results were in favour of Calotropis ex-

Table 1. Radial mycelial growth of fungal strains in control and test plates (in $\mathrm{cm}$ ).

\begin{tabular}{llllllll}
\hline S.N. & Fungal Strains & Control & Clove & Cinnamon & Thyme & Parthenium & Calotropis \\
\hline 1. & Sclerotium & 3.5 & - & 2.1 & 2.3 & 2.8 & 2.9 \\
2. & Alternaria & 2.8 & - & 1.7 & 1.5 & 1.8 & 2.2 \\
3. & Fusarium & 2.5 & - & 1.3 & 1.7 & 2.0 & 1.9 \\
4. & Rhizactonia & 3.9 & - & 1.0 & 2.5 & 3.6 & 3.5 \\
5. & Aspergillus & 3.9 & - & 2.6 & 3.4 & 3.5 & 3.6 \\
\hline
\end{tabular}

Table 2. Radial mycelia growth of fungal strain in control and test plates on treatment of Mancozeb (in cm).

\begin{tabular}{llllll}
\hline S.N. & Fungal Strains & Control & $\mathbf{5 0 0 p p m}$ & $\mathbf{1 0 0 0 p p m}$ & $\mathbf{1 5 0 0 p p m}$ \\
\hline 1. & Sclerotium & 4.2 & 0 & 0 & 0 \\
2. & Alternaria & 2.9 & 1.1 & 0.8 & 0.7 \\
3. & Fusarium & 2.8 & 1.3 & 0.8 & 0.6 \\
4. & Rhizactonia & 4.2 & 2.7 & 1.7 & 0.8 \\
5. & Aspergillus & 4.3 & 2.8 & 2.4 & 2.1 \\
\hline \hline
\end{tabular}


Singh, J. et al. / J. Appl. \& Nat. Sci. 11(2): 333- 337 (2019)

Table 3. Radial mycelia growth of fungal strain in control and test plates on treatment of Nystatin (in $\mathrm{cm}$ ).

\begin{tabular}{llllll}
\hline S. N. & Fungal Strains & Control & $\mathbf{5 0 0 p p m}$ & $\mathbf{1 0 0 0 p p m}$ & $\mathbf{1 5 0 0 p p m}$ \\
\hline 1. & Sclerotium & 4.2 & 0 & 0 & 0 \\
2. & Alternaria & 2.9 & 0.3 & 0.3 & 0.2 \\
3. & Fusarium & 2.8 & 1.7 & 1.5 & 1.2 \\
4. & Rhizactonia & 4.2 & 1.4 & 0.5 & 0.5 \\
5. & Aspergillus & 4.3 & 0 & 0 & 0 \\
\hline
\end{tabular}

Table 4. Economical study of biological fungicides.

\begin{tabular}{|c|c|c|c|c|c|c|}
\hline S. N. & Extracts & $\begin{array}{l}\text { Unit } \\
\text { (Rs./kg) }\end{array}$ & cost & $\begin{array}{l}\text { Concentration } \\
\text { (in \%) }\end{array}$ & $\begin{array}{l}\text { Amount used } \\
\text { (gm in } 50 \mathrm{ml})\end{array}$ & $\begin{array}{l}\text { Total cost } \\
\text { (in Rs.) }\end{array}$ \\
\hline 1. & Clove & 1400 & & 5 & 2.5 & 3.50 \\
\hline 2. & Cinnamon & 1200 & & 10 & 5.0 & 6.00 \\
\hline 3. & Thyme & 600 & & 15 & 7.5 & 4.50 \\
\hline 4. & Parthenium & No cost & & 25 & 12.5 & No cost \\
\hline 5. & Calotropis & No cost & & 25 & 12.5 & No cost \\
\hline
\end{tabular}

Table 5. Economical study of synthetic fungicides.

\begin{tabular}{llllll}
\hline S. N. & Extracts & Unit cost (Rs./kg) & $\begin{array}{l}\text { Concentration (in } \\
\text { ppm) }\end{array}$ & $\begin{array}{l}\text { Amount used } \\
\text { (gm in 50 ml) }\end{array}$ & $\begin{array}{l}\text { Total cost } \\
\text { (in Rs.) }\end{array}$ \\
\hline 1. & Nystatin & $22,16,000$ & 500 & 0.025 & 55.40 \\
2. & & & 1000 & 0.050 & 110.80 \\
3. & & 1500 & 0.075 & 166.20 \\
4. & Mancozeb & \multirow{2}{*}{340} & 500 & 0.025 & 0.01 \\
5. & & & 1000 & 0.050 & 0.02 \\
6. & & & 1500 & 0.075 & 0.03 \\
\hline
\end{tabular}

tracts as an ecofriendly alternative for management of disease (Sasode and Singh, 2013). Srivastava and Singh tested the antifungal potential of Parthenium extract against Alternaria sps. in comparison to Nystatin. The results revealed that extracts can be used as alternative for the development of biofungicides (Srivastava and Singh 2011). Shafique and Shafique applied Parthenium extracts against Fusarium solani which exhibited prominent reduction in the radial growth of colony (Shafique and Shafique, 2012). Similarily, the antimicrobial efficacy of cinnamon extracts were tested against both bacteria and fungi by Gupta and co-worker and results were found effective (Gupta et al., 2008).

Economical comparison between synthetic and biological fungicides: Today, farm level cost includes the cost of the pesticides and their application. This study was conducted under invitro conditions to analyse the farm level economics of synthetic fungicides and its comparison to the biological fungicides. In this study, estimation, after excluding the cost of labour and energy, will be the same for both synthetic and biological fungicides. The quantity and costs of materials were entered into study based on prices from local suppliers.

By studying the data presented in table 4 and 5 , it is evident that Mancozeb is a low cost fungicide and was found effective under in-vitro conditions only against $F$. monilifrome as compared to Nystatin. Nystatin was found to be effective against $S$. rolfsii, $A$. alternata, $R$. solani and $A$. niger under in -vitro conditions but the price range was quite high. Clove was found to be most effective against all the five plant pathogenic fungi with $100 \%$ inhibition and its cost value was moderately less than Nystatin. Though clove is a costly spice but it proved to be effective for deriving profitable economic returns. The present study clearly reflects that Parthenium and Calotropis tested against plant pathogenic fungi shown antifungal activity at concentration of $25 \% \mathrm{w} / \mathrm{v}$. So weeds can also be utilized as biological fungicide in higher concentrations as they cost nothing and on the other hand, our useful cereal crops will get rid of these weeds. This study will provide a useful foundation for further inquiry and more extensive analysis.

\section{Conclusion}

The present study concluded that among five botanical extracts viz. bud of Clove, bark of Cinnamon, seed of Thyme, leaves of Parthenium and Calotropis in different concentrations i.e. 5\%, $10 \%, 15 \%, 25 \%$ and $25 \%$ evaluated for antifungal activity against the test pathogens like S.rolfsii, A.alternata, F.monilifrome, R.solani and A.niger under in-vitro conditions, The spices had inherent ability to induce antifungal effects on mycelia growth rate and consequently on proliferation of these fungi. The clove possessed better antifungal activity as compared to other spices and weeds even at very low concentration and it represented an alternative source of natural biological antifungal substance which will be helpful in preventing the environment from being contaminated. However, further analysis of clove could be done to isolate the antifungal agents present in the spices so that they can use commercially as bioagents. The cost value of spices was higher and was the 
main setback in using them as fungicide, but if health hazards and environment are considered as our priority, then the administration of phytochemicals can be easily adopted. By increasing the concentration of weeds in ethanolic extracts, better results were obtained which will benefit the crops against the allelopathic effect of weeds which are responsible for antifungal activity and will be useful in the formulation of safer and more economical bio-pesticides leading to integrated diseases management.

\section{ACKNOWLEDGEMENTS}

The research work was supported by Graduate Aptitude Test in Engineering (GATE).

\section{REFERENCES}

1. Barreto, M., Critchley A.T. and Straker, C. J. (2002). Extracts from seaweeds can promote fungal growth. Journal of Basic Microbiology: An International Journal on Biochemistry, Physiology, Genetics, Morphology, and Ecology of Microorganisms, 42(5): 302-310.

2. Chen, C.P., Lin, C.C. and Namba T (1987). Development of natural crude drug resources from Taiwan. In vitro studies of the inhibitory effects on 12 microorganisms. Shouyakugaku Zasshi., 41(3): 215-225.

3. Cos, P., Vlietinck, A.J., Berghe, D.V. and Maes, L. (2006). Anti-infective potential of natural products: How to sdevelop a stronger in vitro 'proof of- concept'. Journal of ethnopharmacology, 106(3):290-302.

4. Dreistadt, S.H. (2003). Integrated pest management for floriculture and nurseries (Vol. 3402). University of California, Agriculture and Natural Resources, CA.

5. Farombi, E.O., Ogundipe, O.O., Uhunwagho, E.S., Adeyanju, M.A. and Moody, J.O. (2003). Antioxidant properties of extracts from Alchornea laxiflora (benth) Pax and Hoffman. Phytotherapy Research,17(7): 713 $-716$

6. Florl, C.L., Speth, C., Kofler, G., Dierch, M.P., Gunsilius, E. and Wurzner, R. (2003). Effect of increasing inoculum sizes of Aspergillus hyphae on MICs and MFCs of antifungal agents by broth microdilution method International journal of antimicrobial agents, , 21(3): 229-233.

7. Georgii, A. and Korting, H.C. (1991). Antifungal susceptibility testing with dermatophytes. Mycoses, 34(5 -6): 193-199.

8. GOI (2011). Economic survey 2010-11, Union Budget. Statistical appendice: Economic survey.

9. Gupta, C., Amar, P., Ramesh, C., Uniayal, R.C. and Kumari, A. (2008). Comparative analysis of the antimicrobial activity of clove and cinnamon oil and extract on some food borne microbes. African Journal of Microbiology Research, 2(9): 247-251.

10.Gupta, D. (2013). Comparative analysis of spices for their phenolic content, flavanoid content and antioxidant capacity. American International Journal of Research in Formal, Applied \& Natural Sciences, 4(1): 38-42.

11.llyas, M.B., Nasir, M.A. and Randhawa, M.A. (1982). Chemotherapy of plant diseases. Laboratory Manual: Deptartment of Plant Pathology, University of Agriculture, Faisalabad.

12.Ingold, C.T. and Hudson, H.J. (1993). The biology of fungi. Sixth Edition. Chapman and Hall, New York,

\section{pp 119-132.}

13.Jagtap, G.P., Mali, A.K. and Dey, U. (2013). Bioefficacy of fungicides, bio-control agents and botanicals against leaf spot of turmeric incited by Colletortricum capsici. African Journal of Microbiological Research, 7(18): 1865-1873.

14.Kumar, S. and Gupta, O. (2012). Expanding dimension of plant pathology; JNKVV Res J. 46(3):286-293.

15.Kumar, J. and Saxena, S.C. (2009). Proceedings of the $21^{\text {st }}$ training on Recent Advances in Plant Disease Managment, GBPUA\&T Pantnagar, pp.1-3.

16.Lulekal, E., Kelbess, E., Bekele, T. and Yineger, H. (2008). An ethnobotanical study of medicinal plants in Mana Angetu District, Southeastern Ethiopia. Journal of ethnobiology and Ethnomedicine,4(10):1746-1752.

17.Maregesi, S.M., Pieters, L., Ngassapa, O.D., Apers, S., Vingerhoets, R., Cos, P., Berghe, D.A. and Vlietinck, A. (2008). Screening of some Tanzanian medicinal plants from Bunda district for antibacterial, antifungal and antiviral activities. Journal of Ethnopharmacology, 119: 58-66.

18.McCutcheon, A.R., Ellis, S.M., Hancock, R.E.W. and Towers, G.H.N. (1994). Antifungal screening of medicinal plants of British Columbian native peoples. Journal of ethnopharmacology, 44(3): 157-169.

19.Nair, R., Kalariye, T. and Chanda, S. (2005). Antibacterial activity of some selected Indian Medicinal Flora. Turkish Journal of biology, 29(1): 41-47.

20.Persley, D. (1993). Diseases of fruit crops. Brisbane: Department of primary industries.

21.Rasooli, I. and Abyanek, M.R. (2004). Inhibitory effect of thyme oils on growth and aflotoxin production by Aspergillus parasiticus. Food Control. 15(6):479483.

22.Sasode, R.S. and Singh, P. (2013). Antifungal evaluation of Calotropis leafy extracts against some plant pathogenic fungi. Trends in Biosciences 6(1): 82-85.

23.Satish, S., Raveesha, K.A. and Janardhana, G.R. (1999). Antibacterial activity of plant extracts on phytopathogenic Xanthomonas campestris pathovars. Letter in Applied Microbiology, 28(2): 145-147.

24.Shafique, S. and Shafique, S. (2012). Biological control potential of Parthenium hysterophorus against Fusarium- a cause of Fusarium wilt in potato. International Conference on Applied Life Sciences (ICALS): 315-320.

25.Singh, P. and Srivastava, D. (2013). Phytochemical screening and in vitro antifungal investigation of Parthenium hysterophorus extracts against Alternaria alternate. International Research Journal of Pharmacy, 4(7). ISSN No.2230-8407.

26.Skrinjar, M.M. and Nemet, N.T. (2009). Antimicrobial effects of spices and herbs essential oils. Apteff, 40 $(1-220): 42$.

27.Srivastava, D. and Singh, P. (2011). Antifungal potential of two common weeds against plant pathogenic fungi, Alternaria spcs. Asian Journal of Experimental Biological Sciences, 2(3): 525-528.

28.Strange, R.N. (1993). 'Plant Disease Control: Towards Environmental Acceptable Methods', Chapman \& Hall, London.

29.Tarr, S.A.J. (1962). Diseases of sorghum, sudan grass and broom corn. The Commonwealth Mycological Institute, Kew.

30.Yusuf, N.A., Ibrahim, H. and Khalid, N. (2001). Antibacterial evaluation and tissue culture studies of selected Curama species University of Malaya.. NSF. 